ESSAY REVIEW

\title{
Mediumistic Materializations in France During the Early 1920 s
}

Sessões de Ectoplasmia: Experimentos com Ectoplasma na França de 1920 no Instituto de Metapsíquica Internacional [Ectoplasm Séances: Experiments with Ectoplasm in France in the 1920 at the International Metapsychic Institute] by Antonio Leon. Epígrafe, 2019. 349 pp. ISBN 978-85-65307-32-1.

\author{
Reviewed by Carlos S. Alvarado \\ Parapsychology Foundation \\ carlos@theazire.org \\ https://10.31275/20211843 \\ Creative Commons License CC-BY-NC
}

As I have argued before in this journal, there is a rich tradition of psychical research studies of materialization mediums published before 1930 (Alvarado, 2019a). The phenomenon, associated with many well-known mediums such as Eva C., Florence Cook, William Eglinton, D. D. Home, Franek Kluski, and Eusapia Palladino, has been reviewed by many people during the nineteenth century and later (e.g., Moses, 1884-1886; Richet, 1922, Part 3). Opinions about it have been diverse. In a review of nineteenth-century evidence about it in his book Modern Spiritualism, Frank Podmore (1902, Vol. 2, Chapter 6) was rather dubious about the existence of the phenomenon. In his later concise history of psychical research, Rudolf Tischner (1924) argued that we cannot be sure if "strict proof of the reality of materialization has been provided," but there has been "circumstantial evidence of considerable strength" (p. 68; this, and other translations, are mine). More positively, Charles Richet (1922) wrote in his celebrated Traité de métapsychique that materializations could "take a definitive rank in science" even if "we understand absolutely nothing about it" (p. 690). Over the years these attitudes have been maintained by many writers and students of the 
subject, some of which speculate about vital forces and spirit action. In addition, there have been various reports of fraud with materialization mediums (e.g., Sitwell \& Von Buch, 1880; Wallace, 1906).

Students of the history of materialization phenomena are aware of the studies on the subject by French individuals such as Juliette Bisson and Gustave Geley. This is the main work reviewed by Antonio Leon, who has a doctorate in history from the Federal University of Rio de Janeiro. In Sessões de Ectoplasmia, which focuses on French developments during the 1920s, Leon analyzes materialization phenomena, some of which were studied at the Institut Métapsychique International (IMI) during the 1920s. This book appears at an appropriate time because IMI celebrated their centenary in 2019.

Leon states that in his work about IMI he set out to

investigate how the experiments took place, their organization, the precautions taken to prevent fraud, their procedures of control, the phenomena, their description, and who the mediums were and the investigators involved... [The book] aims to verify the various aspects that pervaded the experiments during the decade of the $1920 s, \ldots$ the values and rules of the investigations of ectoplasm of this period. It will also focus on the research context in which the experiments were located. (p. 19)

Furthermore, Leon proposes that during the 1920s there were two approaches to psychical research. One was a French school mainly interested in physical phenomena such as materializations, and an English one that focused on mental phenomena, a topic I will discuss in more detail later.

The first chapter is about the founding of IMI in 1919, and its early development, a topic discussed by other authors such as Lachapelle (2011). The President of the organization was Italian physician Rocco Santoliquido, and its Director was French physician Gustave Geley (Figure 1). The financial support came from Jean Meyer, a rich wine merchant. But the actual research background came with Geley, who had shown belief in psychic phenomena which he connected to a non-material subconscious mind (Geley, 1899). His initial work with materialization was presented in 1918 in a lecture at the Collège de France entitled "La Physiologie Dite Supranormale et les Phénomènes 
d'Idéoplastie" (Geley, 1918). In this work Geley showed a vitalistic biological and physiological approach to the phenomenon, arguing that supranormal physiology was not more mysterious than conventional physiology. Both depended on the same vital processes, both constructed biological matter, and both were affected by a directing idea that determined organic processes and ectoplasmic formations outside the body. They also had in common that they worked via an organic substance that manifested inside and outside the body. This

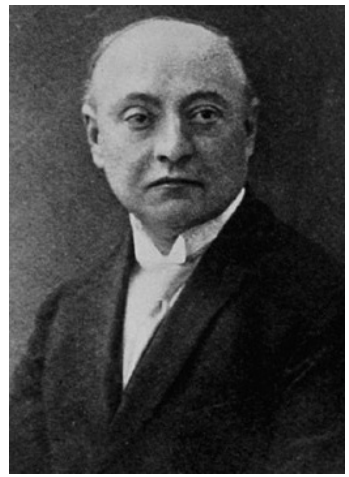

Figure 1. Gustave Geley. substance, Geley stated, was shaped "by a superior dynamism that conditions it, and this dynamism is itself dependent on an Idea" (Geley, 1918, p. 22).

Geley is described by Leon as "the soul of the great scientific movement of metapsychics" (p. 35), whose work nurtured the development of the movement. He became better known in metapsychic studies when he published articles in the Bulletin de l'Institut Métapsychique International, which later changed its title to the Revue Métapsychique. His fame also spread through articles in newspapers and via books that were translated into other languages, such as English: From the Unconscious to the Conscious, and Clairvoyance and Materialisation (Geley, 1919/1920, 1924/1927). Geley stated in a newspaper article that IMI's goal was to contribute to change occultism into science. In this work, he wrote, emphasis will be given to materializations because this phenomenon showed how ideas shaped matter, and "prove that thought is not a product of matter, but that, on the contrary, it is matter that depends on an idea" (Geley, 1919, p. 2).

The second chapter is a short overview about ectoplasm in the 1920s. Leon argued that several factors affected the development of research about ectoplasm in that decade. This includes opposition from different individuals, such as Catholic clergy, some spiritists, "metapsychic researchers from the English School," and traditional scientists (pp. 65-66). To this list I would add critics such as the famous magician Houdini (1924), and the journalist Paul Heuzé (1924).

Of course, not everyone in England was negative about ectoplasm. 


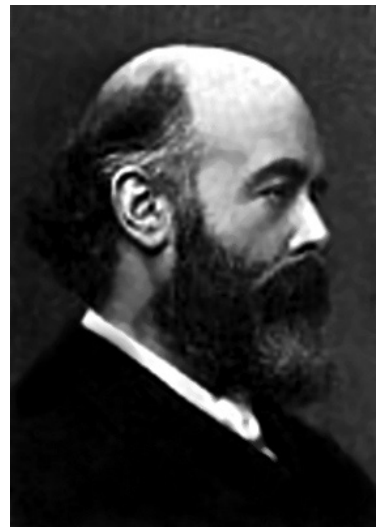

Figure 2. Oliver J. Lodge.

For example, several short papers positive about the concept were published in 1921 in the London spiritualist publication Light by individuals such as William F. Barrett (1921), Stanley De Brath (1921), and Oliver J. Lodge (1921). The well-known physicist Oliver J. Lodge (Figure 2) stated in his article:

All the evidence goes to show that it is an emanation from the medium, and that it returns to the medium's organism ... The curious thing is that it not only gets moulded into organic semblances or temporary organic forms, it, or something associated with it, is able to exert considerable force. The material itself does not seem adapted to do this, and I conjecture that its main function is to nourish and maintain living connection with an ethereal projection of the organism, to which, and not to the superincumbent or permeating matter, the observed forces and energies are primarily due ... (Lodge, 1921)

The author does not give much detail about the researchers he mentions, several of whom are pre-1920s investigators. This includes short comments about William J. Crawford (p. 60) and Enrico Morselli (pp. 61-62), and others whom he only lists, such as William Crookes, Paul Gibier, Enrico Imoda, Pierre Lebiedzinski, and Albert F. von Schrenck-Notzing (p. 61). Many others could be mentioned as well. ${ }^{2}$

There are also three chapters about investigations conducted by Geley. One was devoted to Eva C. and includes the observations of Juliette Bisson, conducted before the founding of IMI. She stated in her book Les phénomènes dits de materialisation that: "The only certain fact seems to be this: The medium gives off a material substance that can be touched and seen" (Alexandre-Bisson, 1921, p. 308).

But the chapter also has sections about Geley's observations in 1917 and 1918 which include, in addition to amorphous ectoplasm, observations of small heads appearing in séances (Figure 3), and comments about the SPR's investigation of the medium. Leon also devotes 

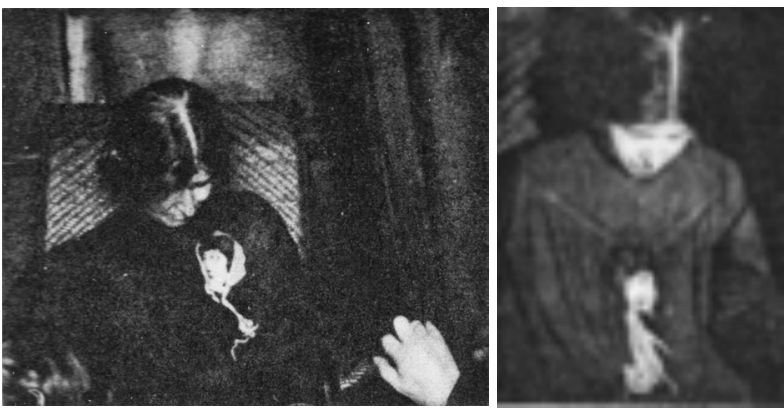

Figure 3. Materialization of small heads in séances with Eva C. reported by Geley (1918). various pages to Geley's critique of the suspicion of fraud by the SPR committee, in particular the comments of Eric J. Dingwall. The fourth chapter is about the materiializations of

Franek Kluski. There is much here about the moulds of hands and feet produced in séances held in both Poland and France (Figure 4). It is important to add, something forgotten by some, that the use of moulds to document the existence of materializations was not new with Kluski. Less-sophisticated examples can be found in the nineteenthcentury spiritualist literature (e.g., Adshead, 1879, pp. 34-39; Denton, 1875). Denton sat with a medium named Emma E. Weston and a cast of a hand was obtained that had fingers and half of the palm. It had a deformation that Denton believed identified it as coming from a deceased friend of his. He wrote that: "The lines of the skin are very perfect over nearly the entire surface; and even the impression of small hairs on the back of two of the fingers can be distinctly seen."

These moulds, considered by Geley to have no conventional explanation, became well-known not only in French psychical research and spiritualist publications, but elsewhere as well. ${ }^{3}$ An article about the hands appeared in the Scientific American. Here Geley (1923)
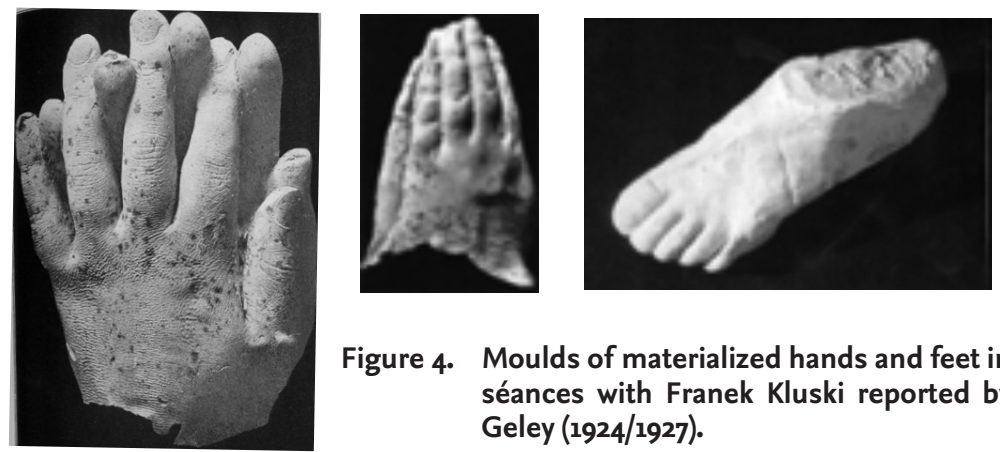

Figure 4. Moulds of materialized hands and feet in séances with Franek Kluski reported by Geley (1924/1927). 
summarized for the American public the features of the phenomena, the precautions taken against fraud in the séances, and some theory. About the latter, also discussed elsewhere (e.g., Geley, 1919/1920, 1924/1927), Geley wrote:

What we know as regards ectoplasmic forms is that the materialized organ is a temporary creation dependent upon the organism of the medium ... What we do not know is from what directing idea the materialization proceeds ... Logically and if we are faithful to scientific method, we ought to explain all ectoplasmic manifestations and materializations by the exteriorization of a part of the organism of the medium in an amorphous state and by the subconscious ideo-plastic organization of the substance so externalized. This is, of course, only a working hypothesis. It seems very narrow to cover the whole of the known facts, and possibly may very soon be found insufficient. But, of course, it is for the present the only hypothesis conformable to positive scientific method. (Geley, 1923, p. 374)

The fifth chapter is about medium Jean Guzik. Many pages are devoted to the phenomena observed with him. The discussion includes the famous Manifest of the 34, a report of individuals who got together to investigate Guzik using strict controls. The report transcended metapsychic circles because it was made public in a newspaper(Ageorges et al., 1923). In addition to Geley, there were several individuals signing the report who were not generally associated with metapsychics. But there were others who were involved with metapsychics, among them Camille Flammarion, Oliver Lodge, Eugène Osty, Charles Richet, Rocco Santoliquido, and René Sudre. The report affirmed the conviction of the signatories that the phenomena observed "are not explainable by illusions nor by individual or collective hallucination, nor by fraud" (Ageorges et al., 1923, p. 2).

The author points out that interest in materializations decreased in IMI after Geley died in 1924 in a plane crash, and the position of Director was filled by Eugène Osty. Osty was more interested in mental phenomena, and he directed his research program in that direction. ${ }^{4}$

Sessões de Ectoplasmia is a valuable contribution of past developments in psychical research, particularly those about French materialization studies related to IMI. Leon reminds us of the 
contribution of Geley and others, as well as of the existence of a research specialty that has almost disappeared today, that of systematic studies of materialization like those conducted with Kluski. The author makes it clear that Geley and others had an empirical orientation, and that they took many measures to control for fraud.

In addition, and as mentioned above, Leon reminds us of differences in emphasis between English and French researchers, something that brings to mind interest in the history of science about the topic of national research traditions and styles (Kwa, 2005/2011). Leon argues for the existence of an English school focused on mental phenomena, and a French one focused on physical phenomena. To support this view, he analyzed unpublished correspondence, such as that between Santoliquido, Richet, and Lodge, and between Bisson and Schrenck-Notzing, as well as Geley's critiques of the SPR investigation of Eva C. The state of mind of SPR investigators, wrote the author, showed a tendency in the 1920 s against physical mediumship, something the French could not understand. "For the French, ectoplasm was the main phenomenon of metapsychics" (p. 316), a phenomenon associated with the mystery of life.

This is consistent with Richet's critique of the SPR. He wrote in his Traité de métapsychique that while the SPR was more accepting of telepathy, when it came to physical phenomena they "demanded impossible proof, even when it is useless for demonstration" (Richet, 1922, p. 10). Such attitudes during the 1920s have been reviewed by Inglis (1984). But it is good to have Leon's reminder of this situation in connection with Geley and the IMI.

Some years ago, I analyzed the content of articles about mental and physical mediumship in the Proceedings of the Society for Psychical Research and in the Revue Métapsychique for the years 1920-1930 (Alvarado et al., 2006, p. 68). The first journal had a higher number of papers about mental instead of physical mediumship (75\% vs. $25 \%$ ), while mental mediumship was less covered in the French journal compared with physical mediumship (21\% vs. $79 \%$ ).

But we need to be careful about generalizing to all SPRconnected individuals, as well as to a whole country. There was not, as stated by Leon, a "common understanding in the England of the decade of the 1920 s against objective mediumship that the ... 


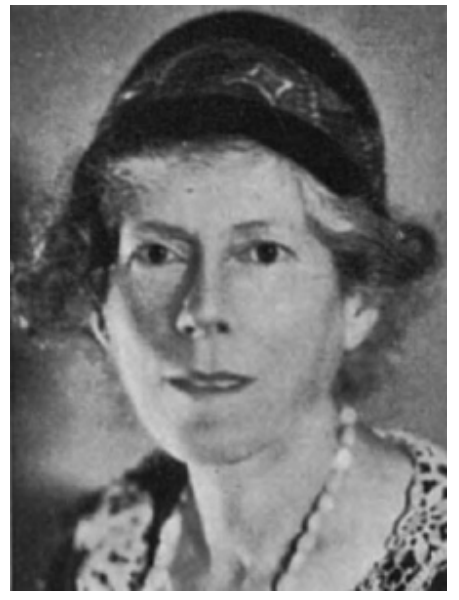

Figure 5. Felicia R. Scatcherd.

[SPR] absorbed at the time" (p. 147). For example, several English researchers who did not represent the SPR—such as Barbara MacKenzie (1924), James Hewat McKenzie (1922), Harry Price (1925), and Felicia Scatcherd (1922)-investigated physical mediumship and defended the reality of the phenomena during the 1920s. Scatcherd (Figure 5), who deserves to be studied further, wrote in an essay:

Ectoplasm was at first understood to indicate the substance exuding from a medium in visible form ... It is now applied to any mode of mediumistic emanation which renders possible the various forms of physical phenomena (including psychic photography) from simple raps to partial or complete materialisations ... (Scatcherd, 1924, p. 130 $)^{5}$

Of course, much more could be done to study approaches to mediumship (and other phenomena) in both countries, a topic beyond the scope of Leon's work. To study these tendencies of preferences for mental mediumship versus physical mediumship, it would be useful to follow the example of studies such as Hardwood's (1993) examinations of communities involved with genetics, and to focus on the institutional structure and goals of both the IMI and the SPR, as well as to conduct a prosopographical study of the researchers in both institutions that will illuminate the educational background of the active researchers in both institutions. ${ }^{6}$

Within the SPR, there were several figures deserving of attention during the 1920s, among them Theodore Besterman, Eric Dingwall, Oliver J. Lodge, J. G. Piddington, and Helen Salter. As argued in a recent study, Lodge's position about physical phenomena and physical ideas was well-known, and was not reductive solely to physical processes (Noakes, 2019). The attitude of the SPR, not necessarily a corporate one, may also be examined in relation to phenomena other than materializations. This could include other aspects of physical 
mediumship, among them spirit photography and telekinesis. In addition, the issue may also be explored with psychical researchers in other countries such as Germany and the United States.

Leon wrote that Geley's procedure was "to observe the facts attentively, without bias, without preconceived ideas, without prejudice of any kind, observing them faithfully, recording them in such a way as to make all mistakes and distortions impossible" (p. 40). However, and not getting into the complex topic of objectivity in science (Padovani et al., 2015), we cannot ignore the fact that observations and data have to be interpreted by a person working within a network of needs, values, and beliefs. Before Geley started his work at IMI he had already committed himself to a non-material belief in the human mind, a mind independent of the nervous system, a belief that was inclusive of psychic phenomena (Geley, 1899). Furthermore, he had developed a biological view of materialization, and its dependence on the influence of an idea, thus helping to further develop the concept of ideoplasty with ectoplasmic forms (Geley, 1918; this is well-summarized by Leon, pp. 64-65). ${ }^{7}$ Such a view certainly influenced his later work on the subject (e.g., Geley, 1924/1927) without diminishing his systematic empirical approach.

This book presents some bibliographical problems, among them incomplete references to articles in the Revue Métapsychique. Furthermore, there is practically no use of the secondary literature on the subject, something that would have helped the author to provide more background information, as well as relevant bibliography for his readers. This includes works such as Zofia Weaver's (2015) study of Franek Kluski. There are also works discussing French metapsychics that include research with materialization phenomena, and that show that there were many examples of negative views in France about IMI's work, particularly during Geley's time. ${ }^{8}$ Some examples of reviews of French psychic studies are M. Brady Brower's (2010) Unruly Spirits: The Science of Psychic Phenomena in Modern France, Sophie Lachapelle's (2011) Investigating the Supernatural: From Spiritism and Occultism to Psychical Research and Metapsychics in France, 1853-1931, and Renaud Evrard's (2016) Enquête sur 150 Ans de Parapsychologie: La Légende de L'esprit. However, Leon made good use of archival materials from the $\mathrm{IMI}$ and reproduced some of them as appendices. 


\section{CONCLUDING REMARKS}

The literature about past observations and ideas regarding materializations is sparse, especially when we consider books solely devoted to the topic, as opposed to works presenting only sections or chapters about it. For these reasons, as well as for the attention to detail and summaries of difficult-to-obtain literature, Antonio Leon's Sessões de Ectoplasmia will be of interest to current students of physical mediumship. It provides a useful window to past interest in these currently neglected mediumistic phenomena and will remind us about aspects of the social dynamics behind such research. One hopes that future studies of materializations will expand on this by including the important work of individuals from other countries, among them the work of German researcher Albert F. von Schrenck-Notzing, who argued that: "The telekinetic process and teleplastic phenomena are only different degrees of the same animistic process and ultimately depend on psychic processes in the subconscious sphere of the medium" (Schrenck-Notzing, 1920, p. 188).

\section{NOTES}

1 See Lodge's earlier speculation (1894, pp. 326-327) about prolongations coming out of Eusapia Palladino's body.

2 Other twentieth-century individuals who studied materializations include Eric Dingwall (1921, 1926), Thomas Glen Hamilton (1929), and Friedrich Schwab (1923). In the latter's view, teleplasm: (1) seems to come only from a medium; (2) emanates mainly from body orifices; (3) can disappear and is sensitive to light; (4) is white or gray, but sometimes appears in other colors; (5) "is fibrous and irregular, mostly one sees honeycomb-like very uneven large, often warped formations" (p. 59); and (6) its density varies.

3 Geley's writings about Kluski attracted attention outside France, as seen in the United States (Geley, 1921/1922a) and Germany (Geley, $1921 / 1922 b)$. There were also many summaries and comments in other languages, such as Italian (II "Medium" Franek Kluski, 1922).

${ }^{4}$ Osty's career is reviewed by Evrard (2016, Chapter 8). I have briefly summarized some psychological aspects of Osty's ESP research (Alvarado, 2019b). 
5 Leon does not get into this, but we should be aware that negative SPR attitudes against physical phenomena preceded the 1920s, as seen in the writings of Frank Podmore and Eleanor Sidgwick (summarized by Gauld, 1968). Writing about the SPR before the 1920s, Rudolf Tischner stated that within "the English researchers' circles it was generally believed that, unless illusions played a role, everything must be attributed to fraud" (p. 223). We should also remember the strong pre-1920s interest in physical phenomena in France. This was evident in the strong magnetic tradition that came up to the twentieth century, as seen with figures such as Albert de Rochas (Alvarado, 2016), and in the interest in physical mediumship evident in the work of individuals such as Charles Richet and Joseph Maxwell (Evrard, 2016).

6 On prosopography, see Clark (2003). Geley's training as a physician must have nurtured his biological and physiological approach, but perhaps most SPR figures had more philosophical-psychological education that promoted interest in mental phenomena. Although Geley was a leading figure, we need to explore the background of others in France, such as those serving in the committee overseeing the IMI (Leon presents information about Santoliquido and Meyer). Some, like Camille Flammarion and Charles Richet, had mixed interests (Evrard, 2016). It is important to remember that, for Geley, the implications of ectoplasm were not physical, but were about the supremacy of the power of the idea over matter, separating consciousness from physical limitations (Geley, 1919/1920), a topic well-summarized by Leon.

7 On the influence of ideas on physical, biological, and psychological processes, see Bozzano's (1926-1927) discussion of the topic. In addition to materialization, he included hypnotic suggestion, thought-forms, psychic photography, and the way mediumship manifests in general. In Bozzano's view, depending much on Geley's ideas, thought and will were forces that shaped the physical and the mental worlds. This, he argued, combated materialism and promoted belief in both survival of death and a pantheistic conception of reality.

8 A well-known example were the critiques of journalist Paul Heuzé (1924), who referred to metapsychics as a "science-if there is such a science-[that] has so far not deigned to consent to use scientific 
methods" (Heuzé, 1924, p. 175). Perhaps in the future, Heuzé wrote, metapsychics will be able to prove its case, and then it would be considered "as one of the most interesting conquests of the human mind" (p. 175).

\section{REFERENCES}

Adshead, W. P. (1879). Miss Wood in Derbyshire: A series of experimental seances demonstrating the fact that spirits can appear in the physical form. J. Burns.

Ageorges, J., et al. (1923, June 7). Les mystères de la métapsychique [The mysteries of metapsychics]. Le Matin, 1-2.

Alexandre-Bisson, J.(1921). Les phénomènes dits de matérialisation: Étude experimentale [The so-called phenomena of materialization: An experimental study (2nd ed.)]. Félix Alcan.

Alvarado, C. S. (2016). On psychic forces and doubles: The case of Albert de Rochas. Journal of Scientific Exploration, 30(1), 63-84.

Alvarado, C. S. (2019a). Musings on materializations: Eric J. Dingwall on "The Plasma Theory." Journal of Scientific Exploration, 33(1), 73-113.

https://doi.org/10.31275/2019.1381

Alvarado, C. S. (2019b). Supernormal knowledge: The work of Eugène Osty. Mindfield, 11(2), 70-74.

Alvarado, C. S., Biondi, M., \& Kramer, W. (2006). Historical notes on psychic phenomena in specialised journals. European Journal of Parapsychology, $21(1), 58-87$.

Barrett, W. F. (1921, May 28). Ectoplasms. Light, 41(2107), 347.

Bozzano, E. (1926-1927). Pensiero e volontà: Forze plasticizzante e organizzanti [Thought and will: Plasticizing and organizing forces]. Luce e Ombra, 26(11), $481-488 ; 26(12), 556-563 ; 27(1), 34-44 ; 27(2-3), 60-69 ; 27(4), 164-175 ; 27(5)$, 223-230; $27(6), 250-262$.

Brower, M. B. (2010). Unruly spirits: The science of psychic phenomena in modern France. University of Illinois Press.

Clark, W. (2003). The pursuit of the prosopography of science. In R. Porter (Ed.), The Cambridge history of science (Vol. 4, pp. 211-238). Cambridge University Press. https://doi.org/10.1017/chol9780521572439.010

De Brath, S. (1921, May 21). Ectoplasms. Light, 41(2106), 331.

Denton, W. (1875, October 16). Casts of spirit hands. Banner of Light, 2.

Dingwall, E. J. (1921). The plasma theory. Journal of the American Society for Psychical Research, 15(5), 207-219.

Dingwall, E. J. (1926). A report on a series of sittings with the medium Margery. Proceedings of the Society for Psychical Research, 36(98), 79-158.

Evrard, R. (2016). Enquête sur 150 ans de parapsychologie: La légende de l'esprit [Investi- 
gation of 150 years of parapsychology: The legend of the mind]. Trajectoires. Gauld, A. (1968). The founders of psychical research. Routledge and Kegan Paul. Geley, G. [under the pseudonym E. Gyel]. (1899). L'être subconscient [The subconscious being]. Félix Alcan.

Geley, G. (1918). La physiologie dite supranormale et les phénomènes d'idéoplastie [The so-called supranormal physiology and the phenomena of ideoplasty]. Bulletin de l'Institut Général Psychologique, 18(1-3), 5-28.

Geley, G. (1919, November 10). La science du mystère s'organise [The science of mystery gets organized]. Le Journal, $1-2$.

Geley, G. (1920). From the unconscious to the conscious. William Collins. (Original work published in French in 1919)

Geley, G. (1922a). Experiments in materialization with M. Franek Kluski. Journal of the American Society for Psychical Research, 17(5), 233-241; 17(7), 381-387; $17(8), 423-429 ; 17(10), 555-562 ; 17(11), 630-636 ; 17(12), 677-687$. (Original work published in French in 1921)

Geley, G. (1922b). Materialisations-Experimente mit Franek Kluski [Materialization experiments with Franek Kluski]. Oswald Mutze. (Original work published in French 1921)

Geley, G. (1923, November). Materialized hands: The Franek Kluski wax molds, and the conclusions that may be drawn from them. Scientific American, 129(5), 316-317, 373-374.

Geley, G. (1927). Clairvoyance and materialization: A record of experiments. T. Fisher Unwin. (Original work published in French in 1924)

Hamilton, T. G. (1929). Teleplasmic phenomena in Winnipeg. Psychic Science, 8(3), 179-208.

Hardwood, J. (1993). Styles of scientific thought: The German genetics community 1900-1933. University of Chicago Press.

Heuzé, P. (1924). L'énigme métapsychique: Où en est-on? [The metapsychic enigma: Where are we?]. Revue de Paris, 31(1), 150-175.

Houdini, [H.]. (1924). A magician among the spirits. Harper \& Brothers.

Inglis, B. (1984). Science and parascience: A history of the paranormal, 1914-1939. Hodder and Stoughton.

Kwa, C. (2011). Styles of knowing: A new history of science from ancient times to the present (D. McKay, Trans.). University of Pittsburgh Press. (Original work published in Dutch 2005) https://doi.org/10.2307/j.ctt5hjswt

Lachapelle, S. (2011). Investigating the supernatural: From Spiritism and occultism to psychical research and metapsychics in France, 1853-1931. Johns Hopkins University Press. https://doi.org/10.1353/book.1855

Lodge, O. J. (1894). Experience of unusual physical phenomena occurring in the presence of an entranced person (Eusapia Paladino). Journal of the Society for Psychical Research, 6(114), 336, 346-360. 
Lodge, O. (1921, May 14). Ectoplasms. Light, 41(2105), 315.

MacKenzie, Mrs H. [B.] (1924). A Scotch materializing and voice medium. Psychic Science, 3(1), 31-40. http://iapsop.com/archive/materials/psychic_science/ psychic_science_v1_nı_apr_1922.pdf

McKenzie, J. H. (1922). Report of Miss Ada Besinnet's mediumship. Psychic Science, $1(1), 19-79$.

II "medium" Franek Kluski [The "medium" Franek Kluski]. (1922). Luce e Ombra, 22(3-4), 116-122.

Moses, W. S. [under pseudonym M. A. Oxon] (1884-1886). Phases of materialisation: A chapter of research in the objective phenomena of spiritualism. Light, 4(157), 9-10; 4(158), 19-20; 4(159), 31-32; 4(160), 41-42; 4(161), 51-52; 4(162), 61-62; 4(163), 71-72; 4(164), 81-82; 4(165), 91-92; 4(166), 101-102; 4(167), 111; 4(168), 121-122; 4(169), 131-132; 4(170), 141-142; 4(171), 151-152; 4(172), 161-162; 4(184), 289-290; 4(185), 299-300; 4(186), 309-310; 4(187), 319-320; 4(188), 329-330; 4(189), 339-340; 4(190), 349-350; 4(193), 381; 4(194), 391-392; 4(196), 413-414; 4(198), 433-434; 4(199), 443-444; 4(200), 459-460; 4(202), 483-484; 5(249), 485; 5(250), 497; 5(251), 508-509; 5(252), 525-526; 5(253), 536-537; 5(254), $548-549 ; 5(255), 560 ; 5(256), 580-581 ; 5(257), 592 ; 5(258), 603-605 ; 5(259), 615-$ 616; 5(260), 627-628; 6(261), 8; 6(262), 19-20; 6(263), 32-33; 6(264), 44; 6(265), $58 ; 6(266), 68 ; 6(267), 80-82 ; 6(268), 92-94 ; 6(269), 105 ; 6(271), 129-130$; 6(272), 135-136; 6(274), 166; 6(276), 188; 6(277), 195; 6(278), 211-212; 6(279), 220; 6(280), 233-234; 6(282), 253; 6(283), 263-264; 6(284), 273-274; 6(285), 281-282.

Noakes, R. (2019). Physics and psychics: The occult and the sciences in modern Britain. Cambridge University Press. https://doi.org/10.1017/9781316882436

Padovani, F., Richardson, A., \& Tsou, J. Y. (Eds.). (2015). Objectivity in science: New perspectives from science and technology studies. In Boston Studies in the Philosophy and History of Science, 310. Springer.

https://doi.org/10.1007/978-3-319-14349-1

Podmore, F. (1902). Modern spiritualism: A history and a criticism (Vol. 2). Methuen.

Price, H. (1925). Stella C.: An account of some original experiments in psychical research. Hurst \& Blakett.

Richet, C. (1922). Traité de métapsychique [Treatise on metapsychics]. Félix Alcan.

Scatcherd, F. R. (1922, March 4). A new light on spirit photography. Light, 42(2147), 134-135.

Scatcherd, F. R. (1924). Ectoplasm as associated with survival. In J. Marchant (Ed.), Survival (pp. 117-133). G. P. Putnam's Sons.

Schrenck-Notzing, A. F. von (1920). Physikalische Phaenomene des Mediumismus: Studien zur Erforschung der telekinetischen Vorgänge [Physical phenomena of mediumship: Studies on research into telekinetic processes]. Ernst Reinhardt.

Schwab, F. (1923). Teleplasma und Telekinese: Ergebnisse meiner zweijährigen 
Experimentalsitzungen mit dem Berliner Medium Maria Vollhart [Teleplasma and telekinesis: Results of my two-year experimental sessions with the Berlin medium Maria Vollhart]. Pyramidenverlag.

Sitwell, G. R., \&Von Buch, C. (1880, January 12). The capture of a spirit. The Times, 11. Tischner, R. (1924). Geschichte der okkultischen (metapsychischen) Forschung von der Antike bis zur Gegenwart. Vol. 2: Von der Mitte des 19 Jahrhunderts bis zur Gegenwart [History of occult (metapsychic) research from antiquity to the present: Vol. 2: From the middle of the 19th century to the present]. Johannes Baum.

Wallace, A. (1906, March 10). Spiritualists unmask a pretender: Exposure of Mr. Eldred. Light, 26(1313), 111.

Weaver, Z. (2015). Other realities?: The enigma of Franek Kluski's mediumship. White Crow Books. 